\title{
Parties, Civil Society, and the Deterrence of Democratic Defection
}

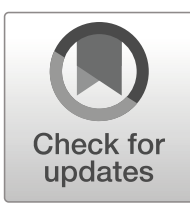

Michael Bernhard ${ }^{1} \cdot$ Allen Hicken $^{2} \cdot$ Christopher Reenock $^{3} \cdot$ Staffan I. Lindberg $^{4}$

Published online: 20 December 2019

(C) The Author(s) 2019

\begin{abstract}
The third wave of democratization has given way to a reverse wave of autocratization. A critical question is what can be done to prevent democratic breakdowns and make democracy endure. A large body of historical-narrative and small-N comparative scholarship has suggested that an active mobilized civil society and institutionalized political parties can be mobilized to protect democracy from authoritarian takeovers. We provide the first rigorous set of empirical analyses to test this argument using data from the Varieties of Democracy (V-Dem) project for the period from 1900 to 2010. We find that both exert a robust, independent, and substantial effect on the survival of democracies. These findings have important policy implications for the international community.
\end{abstract}

Keywords Democratic breakdown · Civil society · Political parties · Accountability · Autocratization

\section{Introduction}

The world is now in a "third wave of autocratization," disproportionally affecting a large number of established democracies (Lührmann and Lindberg 2019). Whether they refer to it as backsliding, recession, rollback, or retreat, numerous scholars and observers document democracy in peril and the threat posed by anti-democratic forces

Electronic supplementary material The online version of this article (https://doi.org/10.1007/s12116-01909295-0) contains supplementary material, which is available to authorized users.

Staffan I. Lindberg

sil@v-dem.net

1 Department of Political Science, University of Florida, Gainesville, FL, USA

2 Department of Political Science, University of Michigan, Ann Arbor, MI, USA

3 Department of Political Science, Florida State University, Tallahassee, FL, USA

4 V-Dem Institute, Department of Political Science, Gothenburg University, Gothenburg, Sweden 
across the world (Bermeo 2016; Brunkert et al. 2018; Diamond 2015; Waldner and Lust 2018). The paramount question facing the international democratic community is what levers can be engaged to counter the threat to democracy.

In the next section, we review the literatures on civil society and political parties that suggest that both-when mobilized and institutionalized-make democracies more durable. Ubiquitous protests against authoritarian populism and populist demagogues suggest that an active citizenry has the potential to defend democracy against threats to its survival (e.g., the protests against Viktor Orbán, Jarosław Kaczyński, and Andrej Babiš in Central Europe (Korolczuk 2016), or the upsurge in protest activity in the USA (8700 protests with six to nine million citizens participating in 2017 alone) in response to the authoritarian tendencies of the Trump administration (Crowd Counting Consortium 2019)). We also know that the collapse of established parties and party systems in cases like Bolivia, Colombia, and Venezuela made democracy vulnerable to collapse (Morgan 2011), and in interwar cases like Belgium, Finland, and Czechoslovakia, the cooperation of establishment parties was able to secure the reequilibration of democracies under threat from fascist challengers (Capoccia 2005).

Despite the widely held belief about the salutary effects of a strong civil society and institutionalized political parties, until recently, comprehensive testing has been difficult if not impossible. The best evidence has come via a combination of historical studies, small-n comparisons, and large-n work on data with limited geographic or temporal coverage. Drawing on newly available data from V-Dem, this article presents the first set of rigorous empirical tests showing that both civil society participation and political party institutionalization exert a strong positive effect on democratic survival, even in the face of substantial controls drawn from tests of democratic survival in the existing literature. The results are robust to concerns about measurement error, model specification, estimator, selection effects, and endogeneity.

\section{How Civil Society and Party Systems Deter Democratic Defection}

Our argument regarding the stabilizing role of civil society and institutionalized parties draws on two different theoretical traditions in the study of democratic stability. Distributionist accounts present durable democracy as a self-enforcing equilibrium where the actors credibly threaten to punish potential defectors (e.g., Przeworski 1991; North et al. 2000; Acemoglu and Robinson 2006; Boix 2003). Institutionalists treat durability as an issue of crisis and reequilibrium, where democratic actors must coordinate the defense of the regime against anti-system extremists (Linz 1978; Capoccia 2005). Consistent with both strands of theory, diverse popular organizations such as political parties, organized interest associations, and social movements can be used to exert mutually enforcing pressure to conform to the democratic rules of the games or to restore democratic equilibria.

Institutionalized parties and active civil societies represent potential safeguards against anti-system activities such as anti-regime protest campaigns, the organization of anti-democratic movements, the rolling back of democratic rules and the distortion of free and fair election results by incumbents, or the organization of coups and putsches. The capability of democratic oppositions and organized citizens to credibly threaten sanctions against anti-system behavior should make democratic institutions 
more effective, and thus make democracy more durable. The channels available to parties and civil society for holding actors accountable can be both formal, for example via legislative or electoral activity, and informal, such as protest and resistance campaigns. Civil society organizations and political parties are thus essential to establishing what North, Summerhill, and Weingast call "credible bounds on the behavior of political officials" with regard to the democratic institutional political order (North et al. 2000, 24).

We expect institutionalized parties and an active civil society to intensify the accountability of elected leaders by both reinforcing the formal checks and balances, and imposing audience costs on would-be democratic defectors, thus creating additional informal channels of accountability. When attempts to defect from the democratic bargain are likely to be met with counter-mobilization, both within and outside the system, this should affect the calculus of would-be defectors and makes democratic institutions more durable. Those who would suspend legislatures, or launch coups, putsches, or revolutions will find their task much harder when the field of politics is populated by effective civil society organizations and political parties that are committed to democracy (for either intrinsic or strategic reasons). This is not the same as saying that all civil society organizations are democratic in nature or that a would-be dictator with a disciplined party cannot be a threat to democracy. Yet, on a systemic level, the on-average density of active citizens and institutionalized political organizations as a whole should matter. Where these are present, nascent autocrats are more likely to face counter-mobilization and resistance, and will find it harder to recruit support. The probability of such non-cooperation should not only affect their prospects of success but also play into their calculations about whether to attempt to subvert democracy in the first place.

While the literatures on civil society and political parties are quite extensive, much of it assumes that institutionalized party systems and active civil societies are beneficial for democracy, and simply use them as the dependent variable. Their development is seen as evidence of higher levels of democracy. The assumptions inherent in these claims have not been subjected to widespread rigorous testing and one of our contributions is to offer the most comprehensive test of these assumptions to date. We concentrate on civil society and parties as independent variables and examine whether more active civil societies and more institutionalized parties contribute to the survival of democracy.

In the sections that follow, we consider the ways in which active civil societies and institutionalized political parties reinforce the accountability mechanisms that make democracy a self-enforcing system. In so doing, we distinguish between the way they impact the various types of accountability identified in the literature (O'Donnell 1998). Vertical accountability refers to the way in which ordinary citizens, collectively constituted as the electorate, can impose constraints on the rulers when regular elections give the power to remove them from office. Horizontal accountability refers to the ways in which different centers of authority constrain one another's actions. To this, we add the notion of social accountability, which is similar to vertical in that it connects citizens to rulers, though exercised informally via direct action (Peruzzotti and Smulovitz 2006; Grimes 2013; Cornell and Grimes 2015; Hegre et al. 2019). These distinctions allow us to specify the pathways through which party and civil society actors can work to reinforce democracy. 


\section{Civil Society}

Civil society is "an organizational layer of the polity that lies between the state and private life...composed of voluntary associations of people joined together in common purpose..." in pursuit of their interests and ideals (Coppedge et al. 2016a, 413). It is populated by groups of citizens organized to pursue common goals. Such civil society organizations (CSOs) include interest groups, labor unions, social movements, professional associations, welfare organizations, among others. They are distinguished from political society (organizations primarily focused on contesting and taking state power like parties) and organized private activity (e.g., spiritual or economic). ${ }^{1}$

The resurgence of civil society as a concept in comparative politics was sparked when widespread citizen activism became a force for resistance (Arato 1993 [1981], Stepan 1985) and democratization (O’Donnell and Schmitter 1986; Przeworski 1991; Rueschemeyer et al. 1992) in a large number of late twentieth century dictatorships. After transition, civil society organizations not only act to promote the interests of their members but also retain their capacity to constrain power by popular engagement. And indeed, there is a growing literature which argues that the strength and character of the civil society that emerges in the struggle for democracy carries over into the operation of democracy in its ability to constrain state power (Rueschemeyer et al. 1992, Haggard and Kaufman 2016, Fishman 2017, Della Porta (2014), Brancati 2016). In terms of the self-enforcement of democracy, this means that an active civil society should be expected to be the mainstay of the social accountability of elites to citizens. ${ }^{2}$

An active civil society not only creates social accountability but also makes vertical accountability more effective. Vertical accountability is predicated on regular elections and the threat they pose to incumbents who are ineffective or unresponsive to citizens. A number of observers have noted limitations to such theories of electoral accountability (Manin et al. 1999; Anderson 2007; Ashworth 2012) given the distal and periodic nature of elections. What keeps politicians accountable between elections, especially if incumbents or challengers are contemplating the overthrow of democracy? The ability of incumbents to avoid being held accountable between elections is demonstrated by the consistency with which electoral authoritarian leaders such as Putin, Mugabe, Chavez, Erdoğan, or Orbán have assailed civil society while consolidating their power (Esen and Gumuscu 2016, 1582, Corrales 2015, 38, Kornai 2015, 37, Bratton and Masunungure 2007, 21, Lipman 2016, 341).

Thus, civil society is essential to checking prerogative state power and keeping politicians accountable to social constituencies, especially between elections. This is attested to by a large literature on how civil society provides alternative forms of

\footnotetext{
${ }^{1}$ Civil society does not include compulsory membership organizations, firms, religious institutions devoted to the practice of spirituality, and criminal organizations. These exclusions do not mean that economic interests or religious believers cannot found civic associations. With regard to economic activity-production is private; union or lobby activities are part of civil society. With regard to religious organizations - saving souls is private; social engagement inspired by belief is clearly part of civil society.

${ }^{2}$ There is also an extensive literature on how active civic engagement produces social trust and thus more effective government growing out of Putnam (1993) and other classics of political culture research. One could argue that effectiveness protects democratic legitimacy and thus deters democratic breakdown via Linz (1978). The connection would look like: civil engagement $\rightarrow$ generalized social trust $\rightarrow$ effective government $\rightarrow$ legitimacy $\rightarrow$ survival. We do not have data to test this causal path nor are we likely to have it in the foreseeable future for a temporally rich cross section of countries.
} 
representation that keep politicians responsive to citizens (i.e., Schmitter 1992; Diamond 1994; Chalmers et al. 1997; Houtzager and Lavalle 2010; Peruzzotti and Smulovitz 2006). Among the mechanisms that may help to promote this are the public pressure exerted by protest and other forms of contentious politics (McAdam and Tarrow 2010; Ekiert and Kubik 1998), the organization of international support and media attention (Keck and Sikkink 1998), the development of citizen-based networks to monitor and oversee government agencies (Smulovitz and Peruzzotti 2000), the utilization of referenda and other popular initiatives for citizen legislation (Altman 2019), and direct intervention via citizen activism to pressure the bureaucracy, the courts, and politicians (Cornell and Grimes 2015).

The overwhelming positive assessment of civil society's impact is countered by another line of research that argues highly mobilized civil societies represent an opportunity for anti-democratic actors to undermine democracy or even a means to take control of the state (Berman 1997; Riley 2010). Such accounts stress that a mobilized civil society, whose demands cannot be effectively channeled by the party system or other institutions, threaten democracy. This view is sharply contested in turn by Bermeo (2003), who asserts that polarization in the public space is often stoked by elites and then in turn used it as an excuse to overthrow democracy. Most of evidence for the negative argument is provided by process-tracing case studies. These accounts are convincing, but the sample is limited to cases of breakdown. In order to test for whether this evidence represents a general tendency or a set of exceptions, we not only test for the additive effects of our two main independent variables but whether they have an interactive effect. If these theories hold, we would expect that a mobilized civil society should be inimical to democratic stability where parties are weak.

The comprehensiveness of the V-Dem data allows us to test the deterrent effect of the social accountability provided by an active civil society. Again, civil society is expected to deter democratic defection not only by reducing the odds that an attempt at subversion will succeed but also by raising the potential costs of subversion. An active civil society therefore should affect the calculus of potential autocrats by diminishing their net payoff if they succeed and lowering their expected utility by increasing uncertainty about their prospects for success. Thus, an active civil society should also be expected to reduce the number of scenarios in which the overthrow of democracy looks like an attractive option.

\section{Political Parties}

Institutionalized parties have strong, stable bases of support, robust organizations, and labels that are distinct and valuable to both voters and candidates (Mainwaring and Scully 1995; Levitsky 1998; Bizzarro et al. 2017). By contrast, weakly institutionalized parties are often ephemeral, with poorly articulated platforms, weak organization, and lacking stable bases of support. In institutionalized party systems, most meaningful competition occurs between established political parties, with relatively stable patterns of inter-party competition (Mainwaring and Scully 1995, Sartori 1976; Mainwaring et al. 2018). The expectation we set out to test in this article is that a higher degree of institutionalization will enhance the prospects for regime survival by strengthening accountability mechanisms, not only vertically and socially as with civil society but also horizontally through party actors in the legislature. 
A number of scholars have posited a link between party/party-system institutionalization and the quality, as well as the stability of democracy. ${ }^{3}$ Party institutionalization is highlighted as a means for channeling the interests of social groups, promoting actors and attitudes supportive of democracy, and facilitating credible commitments (e.g., Mainwaring and Torcal 2006; Ufen 2008; Lewis 2006). Weak or collapsing democratic political parties open the door to anti-system outsiders who threaten democratic institutions (Linz 1994; Samuels and Shugart 2010; Carreras 2012; Mainwaring 2018; Self and Hicken 2018). Weak parties make it harder to hold politicians collectively accountable (Moser and Scheiner 2012; Kitschelt et al. 2010), and create greater uncertainty about actors' preferences, time horizons, and commitment to democracy (Lupu and Riedl 2013; Levitsky 2018; Flores-Macías 2018; Hicken 2016). Finally, party systems with weak parties also produce less-experienced politicians, who, in turn, are "less likely to be unconditional supporters of democracy." (Mainwaring 2018, p 72; see also Kenney 1998) In short, the failure the party system can have fatal consequences for the health and durability of democracy (Morgan 2011).

While we concur with the thrust of these studies, most assert or assume, rather than explicitly test, the relationship between institutionalized parties/party systems and a healthy democracy. As the first study, as far as we know, to systematically test the effect of party institutionalization on democratic survival (or any other democracy indicator) in a cross-national time series framework, our contribution is to verify the nature of the oft-asserted link between party institutionalization and durability.

We place the discussion of party institutionalization and democracy within a survival framework and emphasize how institutionalized parties enhance democratic accountability. First, parties are intrinsic to the electoral process and their ability to displace incumbents when citizens are dissatisfied is central to classic theories of vertical accountability. Second, parties are the dominant actors in legislatures and thus their delegations, both in governing coalitions and legislative oppositions, are central to the operation of institutional checks and balances, i.e., providing horizontal accountability. In these institutional roles, they are also in a position to serve as an early warning alarm in response to potential breaches of the democratic bargain by the executive. Finally, to the extent parties mount extra-governmental campaigns of support and protest among their adherents, they can also play a role in providing the kind of social accountability underscored in our discussion of civil society.

Aspiring dictators (whether incumbents, anti-system movements, or the military) facing institutionalized parties are more likely to face organized opposition if they seek to overturn democratic institutions, compared to those in systems with weak parties. The leaders of institutionalized parties, with their reliable bases of support, robust organizational capacity, and longer time horizons can be expected to have the capacity and incentives to overcome collective action problems in response to attempts by their opponents to defect from the democratic bargain. Thus, similarly to a strong, mobilized civil society, party institutionalization should both increase the costs of democratic

\footnotetext{
${ }^{3}$ Institutionalization itself, as well as a variety of other party-system properties, are also sometimes treated as indicators of the quality of democracy (Mainwaring 1998; Kneuer 2011; Reidl 2014; Mainwaring and Torcal 2006).
} 
defection and reduce its prospects for success. This should help deter attempts to overthrow democracy by decreasing its expected utility.

\section{Concrete Illustration: Slovakia}

The defense of democracy by civil society actors and political parties in Slovakia serves to illustrate how the concerted effort of both can restrain the power of an aspiring dictator. Following the break-up of Czecho-Slovakia in 1993, its politics were dominated by Prime Minister Vladimír Mečiar (1993-1994, 1994-1998) and his party, the Movement for a Democratic Slovakia (HZDS). Mečiar's imperious style resembled that of contemporary rightwing populists. He was a Euroskeptic with a hardline authoritarian style and an exclusionary ethno-national notion of who constituted "the people." During this time period, Slovakia, like many fledgling democracies, had a fairly low level of civil society engagement and a new party system that was just beginning to institutionalize.

The expert consensus is that Mečiar constituted a serious threat to undo democracy (Deegan-Krause and Haughton 2009; Deegan-Krause 2006; O’Dwyer 2006, and Leff 1996). Levitsky and Way (2010, 91) go so far as to categorize the country as competitive authoritarian, though in the data we use, Slovakia does not experience a breakdown. Mečiar used the state-controlled mass media in a blatantly partisan fashion. Independent media were harassed via bogus libel suits and the revocation of licenses for arbitrary reasons (Levitsky and Way 2010, 93). The security services were used to harass opponents via kidnapping, physical intimidation, and wiretapping (Bunce and Wolchik 2011, 62; Deegan-Krause 2006; Leff 1996). Mečiar ignored the results of a referendum on the direct election of the president and defied a Constitutional Court finding ordering him to comply (Haughton 2003, 276-277, 287288). He illegally began to exercise the powers of the presidency when the parliament deadlocked over replacing the outgoing incumbent, Michal Kováč, in 1998.

Ultimately, Mečiar was removed from power by the concerted effort of his opponents, both in the party system and civil society. The dominant force in derailing Mečiar was concerted effort by the parties in opposition. Beginning in 1997, the Christiandemocratic and liberal parties of the center-right (the Christian Democrats, the Democratic Party, and the Democratic Union), all of whom were more civil libertarian, promarket, and pro-EU than Mečiar, adopted a coalition strategy for the upcoming 1998 elections and eventually persuaded the Social-Democrats and the Greens to join (Bunce and Wolchik 2011, 64-65). Despite an underdeveloped civil society, new efforts were launched to oust Mečiar and were broadly supported by a range of existing civil society organizations, such as youth movements, trade unions, and independent think tanks. Three coalitions of CSOs mobilized and played a major role in supporting the parties in the electoral process. The first of these, OK ' 98 (Civic Campaign), did extensive voting education and mobilized first time voters, especially young people. MEMO '98 (Media Monitoring) extensively monitored the pro-Mečiar official state media and publicized distortions in the coverage of elections. OKO '98 (Civic Eye) provided an extensive voluntary network of poll watchers to ensure that the Mečiar forces did not falsify the voting returns (Bunce and Wolchik 2011, 690, Potocki 2011). 
Mečiar's party and its allies saw their share of the vote and seats drop in the parliamentary election of 1998 (Nohlen and Stöver 2010, 1747). The coalition of forces opposed to him, split across four different parties and party coalitions, won almost $60 \%$ of the vote and 80 of the 150 seats in the parliament and were thus able to form a new government under Mikuláš Dzurinda. Despite being a democracy at risk, with a low level of civil society participation compared to many of the democracies in our dataset and a moderate level of party institutionalization, a closer consideration of Mečiar's defeat shows that coordinated action by the opposition parties, combined with an increase in civil society mobilization, derailed his attempt to undermine democracy from a paramount executive position in the system. The defeat of Mečiar demonstrates how concerted efforts by political parties and civil society organizations can resist and defeat leaders who try and use their powers of office to undermine the constraints placed on them by democracy.

\section{Empirical Analysis}

Exploration of the link between party systems, civil society, and democratic durability has been hampered up to now because of the difficulty of collecting cross-national data over a long period of time. Most work in this area relies on single-country or small-n case studies (one exception is Haggard and Kaufman 2016). However, because of batteries of questions which we specifically designed for these purposes in the V-Dem dataset (Coppedge et al. 2016b), the roles of parties and civil society organizations can now be explored in a definitive fashion. V-Dem data on party institutionalization and civil society is available for all states from 1900 to 2010 (more on these data below). Our empirical strategy is to use event history analysis to model a democratic regime's hazard of experiencing breakdown as a function of civil society, party institutionalization, and a set of controls.

\section{Estimation}

Standard event history methods presume that all democratic episodes are vulnerable to experiencing a breakdown and model the effect of covariates on this likelihood. We estimate a series of parametric models, including ones with exponential, Weibull, Gompertz, and Cox specifications of the baseline hazards. Information criteria suggest that the Weibull offers the best fit for our data. The other models are reported in the online supplement in Table S1. The Weibull model assumes a monotonic baseline hazard rate and possesses the proportional hazards property, where the effect of a covariate induces a change in the hazard that is proportional to the baseline hazard, and this change is presumed to be constant over time. We report the test of this proportional hazards assumption in Table S2 in the online supplementary materials. We estimate all of our models with a Gamma shared frailty parameter to account for unobserved heterogeneity across repeated observations. In this fashion, despite including several control variables, we further reduce the possibility that our results are driven by omitted variables that affect survival. We also explored whether our 
results were sensitive to our analysis of repeated cases by estimating conditional risk models, which are reported in Table S3 in the online supplementary materials. Our results are robust across all these analyses.

\section{Dependent Variable}

Our dependent variable is the hazard rate of democratic breakdown. We utilize the Boix et al. (2013) binary measure of democracy which covers the period 1800-2010. We chose their data over the competing ACLP dataset (Alvarez et al. 1996) and its updates due to its longer time frame and the incorporation of an element of suffrage $(50 \%$ male) in its specification of the minimal conditions for democracy. While the two datasets focus on the contestation of electoral offices in their definition, we believe that the incorporation of the suffrage element is important as one moves back in time for capturing the minimal conditions for democracy, in line with Dahl's polyarchy (1971).

For purposes of understanding democratic survival, we include in our sample all democratic country-years and code them as " 0 ." Years in which a country moves from being democratic to authoritarian are coded "1" as breakdown years in line with event history coding. We consider every democratic regime from 1900 to 2010. This restriction is due to the availability of V-Dem data beginning only in 1900. Democratic regimes that break down prior to 2010 are coded as reversals, and those that experienced no breakdown by the end of our temporal window are right censored. The sample includes 4300 country-year observations, with 204 episodes of democracy, 83 of which end in breakdown.

\section{Main Independent Variables}

Here, we review the operationalization and measurement of our key independent variables, party institutionalization and civil society activism. We capture these with an index and an individual variable we created for the V-Dem project, the Party Institutionalization Index (v2xps_party) and the Civil Society Participatory environment (v2csprtcpt) indicator. We created these variables to explore questions such as these, which could not be answered due to problems of data unavailability. V-Dem produces latent variables that gauge social phenomena that are difficult to observe by aggregating ordinal ratings provided by multiple country experts (five or more). The construction of indices combines individual indicators in a second stage. The outputs of multiple indicators are aggregated into indices using Bayesian factor analysis. We briefly review each stage. For a fuller treatment, see Pemstein et al. (2015).

The individual variables are aggregated from the responses that experts provided to questions on the V-Dem survey. These multiple ordinal ratings were aggregated into a unified, continuous and reliable variable using Bayesian item response theory (IRT) models. Because individual raters often vary in the way they interpret the questions, and in reliability and consistency, these models are useful because they incorporate the information encoded in the variation in raters' perceptions and in reliability levels across and within coders into the estimation process (Bollen and Paxton 2000; Jackman 2004). 
IRT models assume that the variable measured is latent, that it cannot be measured directly, and that each coder's response includes a degree of error. The model uses patterns of disagreement across ratings to estimate coder-level errors, and down weighs the ratings provided by coders who are deemed less informative. The Bayesian framework allows us to estimate country-year level parameters that capture the latent variable of interest, along with thresholds differentiating its level. ${ }^{4}$

Estimates of latent variables based on expert opinion pose problems in terms of cross-national comparability. Not only may coders have different assessments of the latent variable, but they may be making their choices according to different thresholds (King and Wand 2007). The existence of distinct scales for different countries would compromise the cross-national comparability of estimates. In order to mitigate these problems, the V-Dem project recruited a large number of bridge coders who serve as connecting units across disjointed countries, and also used anchoring vignettes to gauge the varying cutpoints utilized by different coders. ${ }^{5}$

To generate indices, we used Bayesian factor analysis. As before, utilizing the Bayesian framework is advantageous since it allows us to generate uncertainty estimates for the index. In both cases, all components loaded highly on the latent dimension captured by the indices. Each of these variables has been scaled from 0 to 1 to ease interpretation. An additional benefit of the V-Dem variables is that their data generation process produces both point estimates and measurement uncertainty estimates that afford us the opportunity to estimate both "naïve" models (based on the point estimates) and additional models that take account of the potential measurement error. To demonstrate the utility of the V-Dem approach to data generation, we first estimate and present the naïve models and then compare those findings to those that allow for the possibility of measurement error of both party institutionalization and civil society.

Our variable Party Institutionalization or PI is an index of five indicators from the V-Dem dataset and is designed to capture the extent to which party systems are characterized by parties with distinct programmatic identities, strong ties to groups of voters, and robust organizations (Bizzarro et al. 2017). The five indicators include the degrees to which national level parties have permanent organizations, and party branches, in what fashion they establish linkages with constituents, the degree to which they have public and distinct platforms, and their degree of legislative cohesion. ${ }^{6}$ This index includes both democratic parties and those which are either opposed to or apathetic about democracy.

We operationalize civil society using a measure from the V-Dem data, Civil Society Participatory Environment or CSPE. CSPE was designed to measure the extent to

\footnotetext{
${ }^{4}$ The Bayesian regressions provide full posterior distributions for each parameter. Our point estimates are the means of these distributions. In addition, we leverage a hierarchical structure in which we estimate coder specific thresholds, and cluster these around country-level thresholds, which are based on the country for which a given rater has provided the longest time series. In turn, these country-level thresholds are modeled as random deviations from global, variable level thresholds.

${ }^{5}$ Bridge coders, experts who code more than one country, are used to enhance cross-national comparability. Extensive Monte Carlo simulations provide strong evidence that bridge coders indeed improve model fit and greatly increase the degree of cross-national comparability (Pemstein et al. 2015; Marquandt and Pemstein 2017).

${ }^{6}$ For greater detail on how we measure variable Party Institutionalization, see section one of the electronic supplementary materials.
} 
which the citizenry is actively involved in civil society organizations. Responses here run from state control of organizations to situations in which there is a diversity of CSOs in which citizens are active. ${ }^{7}$ The CSOs encompassed in this measure include both those supportive of democracy and those opposed.

For democracies that never experience a breakdown, the mean value of civil society is 1.588 with a standard deviation of 0.793 , while the mean value for party institutionalization is 0.808 with a standard deviation of 0.165 . There is considerably more variation among those democracies that have experienced a breakdown. For these observations, we see, predictably, the mean value of civil society is lower at 0.632 with a standard deviation of 1.064 , while the mean for party institutionalization is 0.642 with a standard deviation of 0.204 .

We also note that the dominant pattern of variance in these measures is crosssectional rather than within episode. For the vast majority of episodes civil society and party institutionalization emerge early, partially shaped by their authoritarian legacies (Bernhard and Karakoç 2007; Hicken and Kuhonta 2014; Rueschemeyer et al. 1992) and the dynamics of their transitions. The relative size of the between standard deviations to the within standard deviations for CSPE and PI is 2.237 and 3.803 times larger, respectively. This is a stark difference when compared to the variance of GDP per capita among our democratic episodes. GDP per capita is more balanced, with a ratio of 0.929 . As a result, the variance that we will exploit in this investigation is between democratic episodes.

\section{Control Variables}

We use a battery of controls to account for potential confounding relationships between our key variables and democratic regime survival. The most important of these concerns the level of modernity, an association first showed by Lipset (1959) and demonstrated as a critical correlate of survival by Przeworski and Limongi (1997). We operationalize this as the natural log of GDP per capita. Because of the strong association between economic crisis and democratic breakdown, we also include change in GDP per capita as well (Gasiorowski 1995). To maximize our temporal and geographic coverage, we use the latest data from the Maddison project (2013). Given their temporal availability, we draw additional controls from the replication set for Svolik's influential piece on democratic consolidation (2008). This includes the type of executive. We include dummy variables that capture presidential and mixed executives (dyarchical forms), with parliamentarism as the reference category. Because of the potential negative ramifications of past military regimes (Cheibub 2007), we include a series of dummy variables for the form of antecedent authoritarianism-military, civilian, monarchical, with a country not having been independent prior to the transition serving as the reference category. We also include controls for the negative impact of past colonial status (Bernhard et al. 2004) binary measures for never colonized and British colony, with other colonizing powers as the reference category. We also include controls for the proportion of democracies in the state's geographic region as well as controls for resource

\footnotetext{
$\overline{{ }^{7} \text { For greater detail on how CSPE }}$ was measured see section two of the electronic supplementary materials.
} 
dependency (revenues from oil, gas, coal and metals as a percentage of GDP), repressive state capacity as size of the military (military personnel as a percentage of the population), land equality (the percentage of land cultivated by family farms), and urbanization (urban population percentage). Each of these measures is taken from Miller (2015). Last, we include a control for ethnic fractionalization, compiled from the CREG dataset (Nardulli et al. 2012).

\section{Evidence from Multivariate Analysis}

Table 2 in the Appendix attached to this paper reports the naïve (assuming no non-random measurement error in our two main variables) multivariate analysis in which we estimate four models. Model 1 is a base model which includes the CSP and PI variables and shows that additively both exert a significant effect in warding off democratic breakdown. In the second model, we estimate an interaction term between CSP and PI to test whether weak parties in conjunction with strong civil societies constitute a dangerous set of conditions for democratic survival. We do not find evidence of such an interaction, indicating that the cases on which this theory is based constitute a set of exceptions, rather than the tendency in the global sample we use here. We also estimate models 3 and 4 with additional control variables to ensure that our analysis is not spurious. We estimate these final two models separately given that several of the additional control variables have greater missingness across our cases. Our findings are robust to all of these specifications. ${ }^{8}$

Figure 1 displays the hazard rate coefficients for our Weibull event-history estimates from model 2 . The estimates for both civil society and party institutionalization are aligned with our expectations. Democracies with an active civil society and well-institutionalized parties are associated with a lower likelihood of regime collapse. These associations are rather sizeable. Democracies with a more entrenched civil society, or an increase of 0.95 (one standard deviation), are associated with a $68 \%$ reduction in the hazard of breakdown. Democracies with more institutionalized parties, or an increase of 0.19 (again, about a standard deviation), are associated with a $45 \%$ reduction in the hazard of breakdown. To appreciate the relative size of these associations, consider the effect of wealth on the hazard of breakdown. Compared to democracies at \$2000 of GDP/capita, those at $\$ 4000$ are expected to have a $49 \%$ reduction in the hazard of breakdown. Or democracies that experience an economic contraction of $10 \%$ are expected to have a $56 \%$ increase in the hazard of breakdown. It is important to remember that these results are generated by using the V-Dem point estimates for these country years. Subsequently, when we model potential measurement error generated by our item response theory model to generate the data, we see a modest reduction in magnitude of these effects, but the overall story is the same.

\footnotetext{
${ }^{8}$ In addition, we also estimated a model in which we employed multiple imputation to fill in missing data on these additional control variables. We estimated 5 imputed datasets using a multivariate normal regression to generate values for missing data. We report the average estimates from these imputed data in the electronic supplementary materials in Table S4. Our results are robust to these imputed estimations.
} 


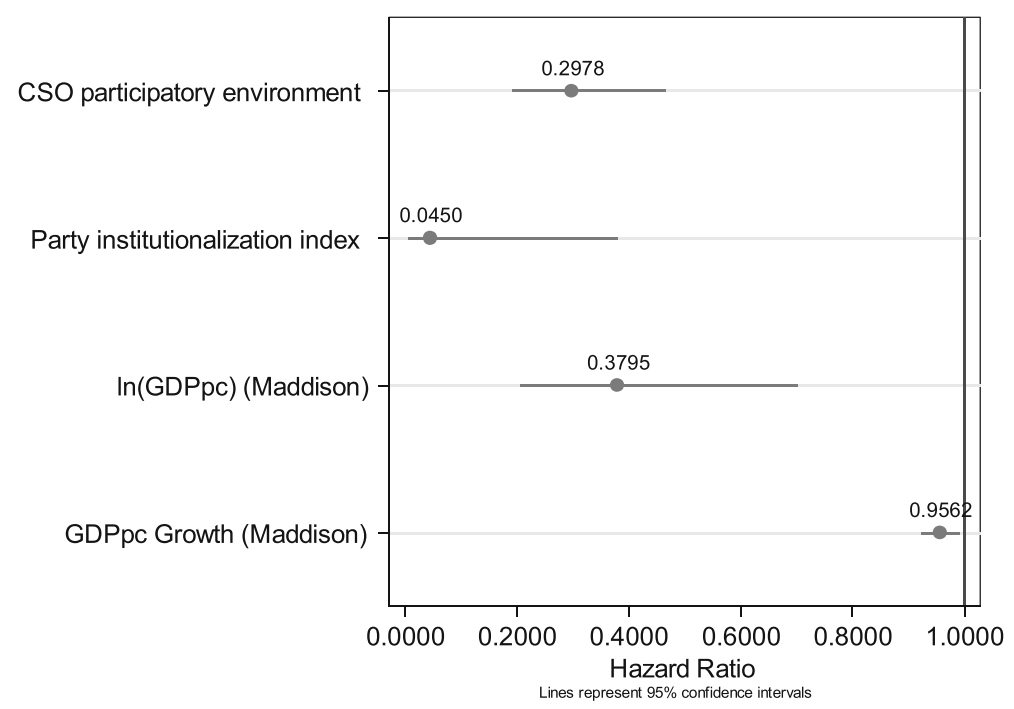

Fig. 1 Hazard coefficient plots of civil society, party institutionalization, and select controls

\section{Endogeneity Concerns: Identification and Theoretical Implications}

Now that we have presented our multivariate analysis, we consider whether the relationship between civil society, party institutionalization, and regime survival operates in the direction we hypothesize. The possibility exists that we could have the direction of the relationship reversed. One could plausibly argue that as the breakdown process begins that civil society and the parties are eroded as a part of that process. If this is the case, there is the danger than any relationship we find between the state of political parties and civil society and breakdown is not in the direction we claim.

Fortunately, we can leverage our data to explore the plausibility of this alternative story. If this is the case, then we would expect our results to be driven by within-case variation. If we see a pattern of weakening civil society and parties consummate with breakdown, then we should rightly be concerned. However, our data present precisely the opposite picture. We note that both our indices are relatively time invariant within given cases. We see little within case variation in either party institutionalization or civil society for lengthy periods of time across democratic episodes, limiting the possibility that the hazards a regime may face will also influence either of these institutions. Consistent with our theory, and contrary to the alternative, our results are driven overwhelmingly by between-case variation, not within-case changes.

To assure ourselves that the strength of political parties and civil society robustness are operating in the ways outlined in our theory, we identify implications that we expected each to have on other behaviors associated with democratic survival. Taking into account the sort of anti-democratic behavior identified by Linz (1978) in his classic study of democratic breakdown, we identify two behavioral outcomes that are linked with democratic survival and, if our theory is correct, to our two key independent variables. First, we expect that developed parties and civil society organizations will effectively incorporate interests into the democratic system while also acting as a 
deterrent to anti-system behavior. Second, we expect that strongly institutionalized party and civil society sub-systems will promote greater confidence in the democratic rules of the game. Specifically, we expect that actors will be more likely to accept electoral results as legitimate in systems with high levels of party institutionalization and an active civil society. We explore these implications in Table 1 by looking at the correlation between PI and CSPE and variables that capture these effects. We also consider two popular institutional variables that scholars have sought to link to democratic regime collapse, with varying empirical success - a military legacy under authoritarianism and a presidential executive.

The first two variables, "protest directed at regime change" and the "number of anti-system movements," assess the emergence of actors seeking to overthrow the democratic system. ${ }^{9}$ On the whole, in both cases we see moderately negative correlations with both PI and CSPE and similar positive correlations for military legacy and presidential systems. It is important to note that the protest variable does not measure protest activity, generally, but only protests aimed at overthrowing the system in our sample of democratic country-years. We would expect democracies to have normal institutionalized cycles of protest, but this is not what we are measuring here. Rather, we focus only on those protests that have as their goal regime change, and find that such protests are less likely where PI and CSPE are high. We also see that both are associated with a lower number of political movements geared towards system change. In both cases, as we might expect, military legacy and presidential systems are positively correlated with these behaviors.

Finally, the third variable explored here, "do losing parties accept electoral results," addresses whether political parties that lose elections challenge the results. ${ }^{10}$ This speaks to the effect of stronger party and interest representation in building compliance norms and deterring challenges to electoral outcomes. In both cases the relationships are as we would expect. Where PI and CSPE are high, electoral losers are more likely to abide by the results, with PI having a particularly strong effect. Again, military legacy and presidential systems are negatively correlated with this behavior and are roughly half the strength as PI and CSPE.

\section{Measurement Error}

Our analysis has used the V-Dem point estimates of PI and CSPE. However, VDem data are based upon expert coding inputs to a larger measurement model. As such, there is measurement error associated with any of the point estimates reported by the V-Dem posteriors. V-Dem also provides posteriors from the project's measurement model which enables us to allow measurement error to propagate throughout our estimates. By doing so, we can estimate the effect that any uncertainty in the estimation of the two variables has on the inferences we draw from our analysis.

\footnotetext{
9 The data for "protest directed at regime change" come from the Nonviolent and Violent Campaigns Dataset 2.0 and cover the period 1945-2006 (Chenoweth and Lewis 2013). The data on "number of antisystem movements" comes from V-Dem - v2csantimv (Coppedge et al. 2016b).

${ }^{10}$ The data on acceptance of electoral results comes from V-Dem - v2elaccept (Coppedge et al. 2016b).
} 
Table 1 Party institutionalization and civil society participation and anti-democratic behavior

\begin{tabular}{lllll}
\hline & $\begin{array}{l}\text { Party } \\
\text { Institutionalization } \\
\text { index }\end{array}$ & $\begin{array}{l}\text { Civil society } \\
\text { participation }\end{array}$ & $\begin{array}{l}\text { Military } \\
\text { legacy }\end{array}$ & $\begin{array}{l}\text { Presidential } \\
\text { system }\end{array}$ \\
\hline Protest directed at regime change & -0.2665 & -0.1840 & 0.2407 & 0.2688 \\
Number of anti-system movements & -0.4197 & -0.2091 & 0.2140 & 0.1507 \\
Do losing parties accept electoral results? & 0.6363 & 0.4415 & -0.2527 & -0.3247 \\
\hline
\end{tabular}

$n=1336$

To allow measurement error to propagate through the model we adopt an iterative Monte Carlo procedure known as the "method of composition," used by Trier and Jackman (2008) and Pemstein et al. (2010). V-Dem provides 900 draws from their measurement model's posteriors. We used these data to repeat our event history model 900 times.

Figure 2 plots the posterior distributions for each of the variables derived via the method of composition. First, it is clear that measurement error in the development of these indices from V-Dem does propagate through to our estimates of the hazard coefficients for these factors. Each of these distributions suggests a consistently supportive role of civil society and party institutionalization for democratic regime survival given that $100 \%$ of the civil society estimates and $95.9 \%$ of the party institutionalization parameters fall below a hazard rate of 1.0. The mean of the posteriors suggests that measurement error has attenuated the MLE estimates; however, these institutions are still beneficial for democracies. In the absence of measurement error, an increase in civil society of 0.95 on our 1 to 0 scale (about a standard deviation), was associated with a $68 \%$ reduction in the hazard of breakdown. With measurement error, we now estimate this reduction to be $63 \%$. Similarly, in the absence of measurement error, an increase in party institutionalization of 0.19 on our 1 to 0 scale was associated with a $45 \%$ reduction in the hazard of breakdown. With measurement error, we now estimate this association to be a $14 \%$ reduction. Incorporating measurement error in our estimates allows the uncertainty inherent in the indices to temper our inferences.
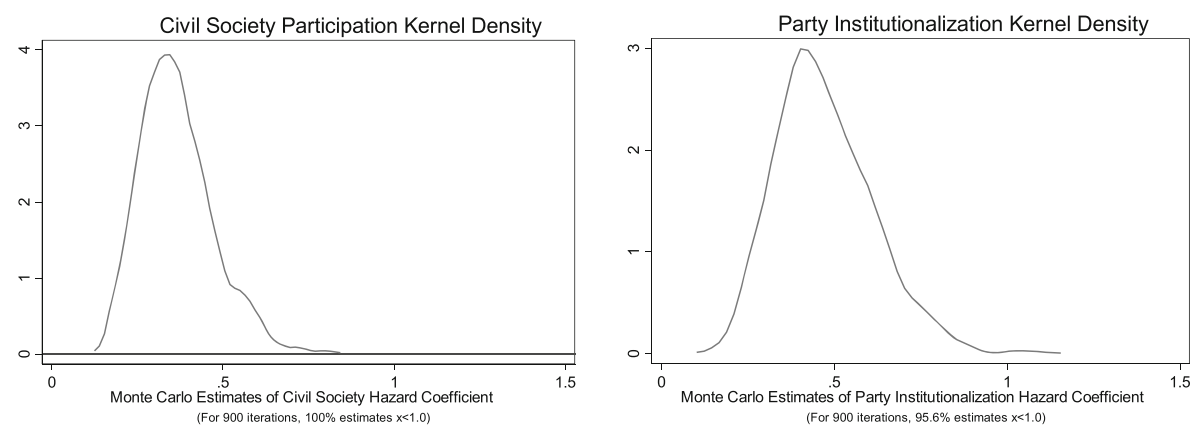

Fig. 2 Hazard coefficient plots of civil society index, party institutionalization index, and select controls 


\section{Scope Condition Concerns}

There are a variety of ways in which democracy dies. Our findings above show that the basic logic of our theory holds for an extensive sample containing a variety of types of democratic breakdown. Institutionalized parties and organized civil society, possessing the capacity to deter and mobilize against attempts to subvert democracy, raise the costs of defection for nascent autocrats and therefore make defection less likely, ceteris paribus. Yet, at the same time, the literature has identified several distinct paths to democratic breakdown, and it would behoove us to consider if the prophylactic powers of civil society and party institutionalization are less effective under any of these sets of conditions.

The most comprehensive accounting of breakdown paths was compiled by Linz (1978):

- Civil War - the democratic middle disintegrates, two relatively equal camps emerge, and the armed forces of the country split, disintegrate, or are unwilling to intervene.

- Military coup - the military takes control by force.

- Putsch-takeover of power from below by a well-organized disloyal opposition unwilling to share power.

- Emergency suspension of democracy by a sitting democratic governmentinterruption of democracy in order to restore order and democratic equilibrium using extraordinary measures.

- Autogolpe - a political faction takes power by democratic means and then uses its position of power to undermine its competitors and to seize control of the state.

To this, we would add sustained democratic deterioration as an evolutionary path to competitive authoritarianism.

The question remains whether we think that the ability of institutionalized parties and an active civil society to raise the costs of democratic defection is sufficient to overcome the syndrome of problems associated with each of these pathways. The one form of breakdown for which we believe the deterrent logic may not hold is civil war. This is likely because we believe civil war scenarios entail extreme levels of polarization which social and political organization will not contain, or even to which their organizational resources could contribute. In order to test this, we run a set of competing risks survival models that gauge the relative risk of active civil societies and institutionalized parties in deterring democracies from breaking down by civil war in contrast to other pathways. The results appear in Appendix Table 3. The models (2, $4,6)$ that look at the non-civil-war pathways behave very much in line with our main models, demonstrating the deterrent effect. In contrast, in models 3,5 , and 7 , active civil societies and institutionalized parties seem to have little effect in deterring civil war breakdowns. The coefficients for civil society are consistently under one (a reduced relative risk) but it only attains significance in the model that uses Fearon's civil war coding (5). The coefficients for party institutionalization are never statistically significant.

These results suggest that the deterrent effects of an active civil society and institutionalized parties against anti-system forces are not effective in the presence of 
civil war. Of course, civil wars are not randomly distributed among democracies. If party systems and civil society participation are associated with civil war emergence, then we may have incorrectly inferred their irrelevance to democratic breakdown. We test this possibility in Appendix Table 4 examining the association between active civil society and institutionalized parties and civil war onset. The results for both variables in the two specifications presented in A3 are insignificant thus closing off this alternative.

\section{Conclusion}

With a "third wave" of autocratization currently affecting both new and established democracies and anti-democratic movements active globally, what means do those who seek to preserve democracy have at their disposal to counteract this threat? A large body of scholarship suggests that an active civil society and institutionalized political parties make democracies more durable in the face such challenges. The novel and finegrained cross-sectional time series data on civil society participation and the institutionalization of political parties provided by V-Dem, makes it possible to provide a rigorous assessment of whether this is really the case. This article is the first to demonstrate with a set of comprehensive rigorous empirical analyses that citizens organized in parties and civil society organizations provide credible threats through formal and informal pathways of democratic accountability. This deters other actors from defecting from democratic bargains, thus enhancing democratic durability.

Our results thus suggest that the integrity of democratic institutions is protected by the ability of democracy-supporting actors to mobilize in defense of their interests. Institutions become more than mere parchment when they become focal points for collective and coordinated action. We are not the first to find evidence of such mechanisms. The literature on courts has shown that the public's willingness to punish those who might interfere with judicial independence is essential to its perseverance (Staton 2010; Vanberg 2001, 2005). Our results here underscore a similar, broader role for the organized public's ability to hold elites institutionally accountable in ways that protect a democratic regime's survival.

Our collection of global data via V-Dem has provided us with the opportunity to incorporate rich data on civil society and political parties as the realms in which organized actors with a stake in democracy have the potential to use mechanisms of democratic accountability to provide credible threats to, and impose costs on, those who would undermine democracy. Using the econometric methods prevalent in the survival literature, we provide evidence that shows that both institutionalized parties and active civil societies are strong covariates of survival, controlling for the main variables in the literature. This result is robust to a number of other event history parameterizations and is durable when we allow the error inherent in the two main independent variables to propagate via iterative Monte Carlo simulations using the method of composition.

We also show that the effects of both civil society participation and party institutionalization are independent and additive. We find no evidence that imbalances between the two subvert their protective effects over the large number of cases that our sample encompasses, despite the documented findings of high visibility small-n studies (Berman 1997, Riley 2010). 
If the essence of democracy is the representation of the interests of diverse actors in a fashion that allows them to determine who holds power in peaceful, regular, and openended fashion, the degree to which those interests are effectively organized should be consequential for deterring the arbitrary seizure and exercise of power. With the force of the combined evidence from the present large- $\mathrm{N}$ and longitudinal approach and the large number of comparative and historical process tracing case studies, we conclude that a strong civil society and institutionalized political parties should be seen as bulwarks to ensure democratic stability and whose resilience the international community should support in the face of the current wave of autocratization. This is an important and essential insight for this day and age in which democracy seems imperiled globally.

Funding Information Open access funding provided by University of Gothenburg.

\section{Appendix}

Table 2 Democratic survival by civil society and party institutionalization

\begin{tabular}{|c|c|c|c|c|}
\hline & Model 1 & Model 2 & Model 3 & Model 4 \\
\hline \multicolumn{5}{|l|}{ Reversals } \\
\hline \multirow[t]{2}{*}{ Civil society } & $0.2978 * * *$ & $0.2860 * * *$ & $0.3699 * * *$ & $0.4120 * * *$ \\
\hline & 0.0680 & 0.1384 & 0.1001 & 0.1056 \\
\hline \multirow[t]{2}{*}{ Party institutionalization } & $0.0450 * * *$ & $0.0446 * * *$ & $0.0479 * *$ & $0.0345 * *$ \\
\hline & 0.0490 & 0.0487 & 0.0574 & 0.0493 \\
\hline \multirow[t]{2}{*}{ Civil society $\times$ party institutionalization } & - & 1.0725 & - & - \\
\hline & - & 0.7684 & - & - \\
\hline \multirow[t]{2}{*}{$\ln (\mathrm{GDPpc})$} & $0.3795 * * *$ & $0.3790 * * *$ & $0.2124 * * *$ & $0.2874 * *$ \\
\hline & 0.1190 & 0.1194 & 0.1179 & 0.1649 \\
\hline \multirow[t]{2}{*}{ GDPpc growth } & $0.9562 * *$ & $0.9561 * *$ & $0.9493 * *$ & $0.9052 * * *$ \\
\hline & 0.0178 & 0.0178 & 0.0213 & 0.0261 \\
\hline \multirow[t]{2}{*}{ Presidential } & 1.2068 & 1.2079 & 0.4734 & 0.6631 \\
\hline & 0.8087 & 0.8099 & 0.3438 & 0.5578 \\
\hline \multirow[t]{2}{*}{ Mixed } & 2.2437 & 2.2294 & 0.4039 & 0.5847 \\
\hline & 1.5376 & 1.5323 & 0.3246 & 0.5383 \\
\hline \multirow[t]{2}{*}{ Prior regime military dict. } & $4.4480 * *$ & $4.4451 * *$ & $3.1454 *$ & $5.1475 * *$ \\
\hline & 2.8155 & 2.8116 & 2.1425 & 3.9523 \\
\hline \multirow[t]{2}{*}{ Prior regime civilian dict. } & 2.0230 & 2.0207 & 1.8437 & 2.5644 \\
\hline & 1.3407 & 1.3382 & 1.2516 & 2.0418 \\
\hline \multirow[t]{2}{*}{ Prior regime monarchist dict. } & 0.6079 & 0.6168 & $0.1044 *$ & $52.7402^{*}$ \\
\hline & 0.6178 & 0.6291 & 0.1314 & 109.7683 \\
\hline \multirow[t]{2}{*}{ Never former colony } & 1.4481 & 1.4475 & 1.6428 & 1.6545 \\
\hline & 1.0908 & 1.0901 & 1.3655 & 1.6445 \\
\hline \multirow[t]{2}{*}{ Former British colony } & 0.7389 & 0.7395 & 0.3481 & 0.7892 \\
\hline & 0.4882 & 0.4879 & 0.2835 & 0.6961 \\
\hline
\end{tabular}


Table 2 (continued)

\begin{tabular}{|c|c|c|c|c|}
\hline & Model 1 & Model 2 & Model 3 & Model 4 \\
\hline \multirow[t]{2}{*}{ Percent democracies in region } & $0.9823 * *$ & $0.9822 * *$ & $0.9750 * * *$ & $0.9654 * * *$ \\
\hline & 0.0083 & 0.0083 & 0.0092 & 0.0117 \\
\hline \multirow[t]{2}{*}{ Resource dependence } & - & - & 1.0304 & 1.0275 \\
\hline & - & - & 0.0263 & 0.027 \\
\hline \multirow[t]{2}{*}{ Military size } & - & - & 0.9886 & 1.1664 \\
\hline & - & - & 0.3418 & 0.5386 \\
\hline \multirow[t]{2}{*}{ Land equality } & - & - & 0.984 & $0.9724 * *$ \\
\hline & - & - & 0.0121 & 0.0132 \\
\hline \multirow[t]{2}{*}{ Urbanization } & - & - & 1.0194 & 1.0111 \\
\hline & - & - & 0.0194 & 0.0225 \\
\hline \multirow[t]{2}{*}{ Literacy } & - & - & 1.0007 & 0.9873 \\
\hline & - & - & 0.0144 & 0.0186 \\
\hline \multirow[t]{2}{*}{ Ethnic fractionalization score } & - & - & - & $0.0503 *$ \\
\hline & - & - & - & 0.0891 \\
\hline \multirow[t]{2}{*}{ Constant } & $54.44 * * *$ & $55.61 * *$ & $15904.49 * *$ & $15577.86^{* *}$ \\
\hline & 123.12 & 127.14 & 62990.89 & 773.94 \\
\hline Weibull shape parameter $(p)$ & $1.9864 * * *$ & $1.9812 * * *$ & $1.8640 * * *$ & $2.0202 * * *$ \\
\hline Frailty variance & $1.6346 * * *$ & $1.6235 * * *$ & $1.1102 * *$ & $1.2316^{*}$ \\
\hline AIC & 245.52 & 247.511 & 225.105 & 187.821 \\
\hline $\mathrm{BIC}$ & 339.56 & 347.82 & 345.55 & 309.49 \\
\hline Failures & 68 & 68 & 58 & 49 \\
\hline Episodes & 150 & 150 & 139 & 126 \\
\hline Cases & 3903 & 3903 & 3048 & 2425 \\
\hline
\end{tabular}

Weibull coefficients are hazard rates

$* p<.10 ; * * p<.05, * * * p<.01$, two-tailed tests 


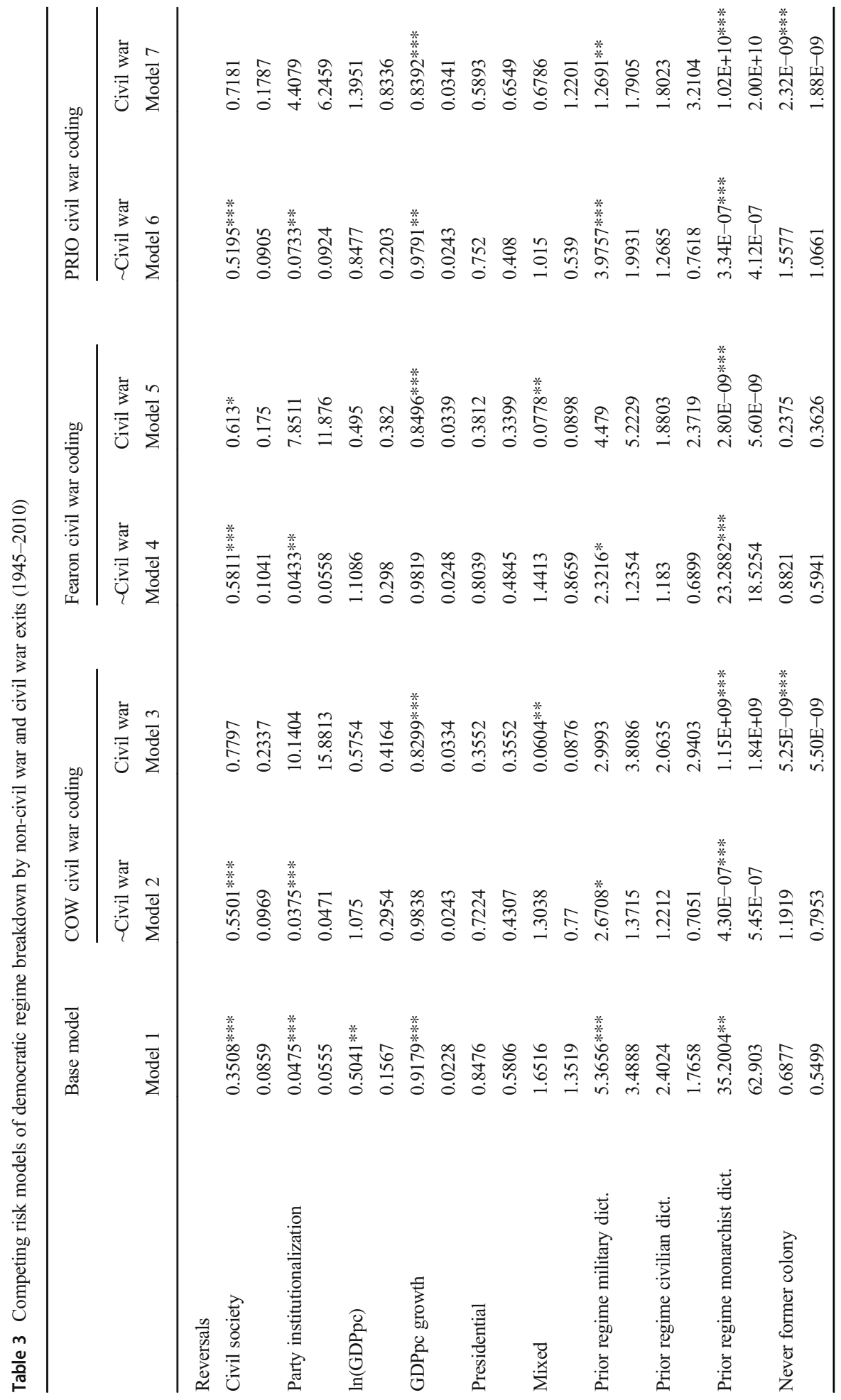




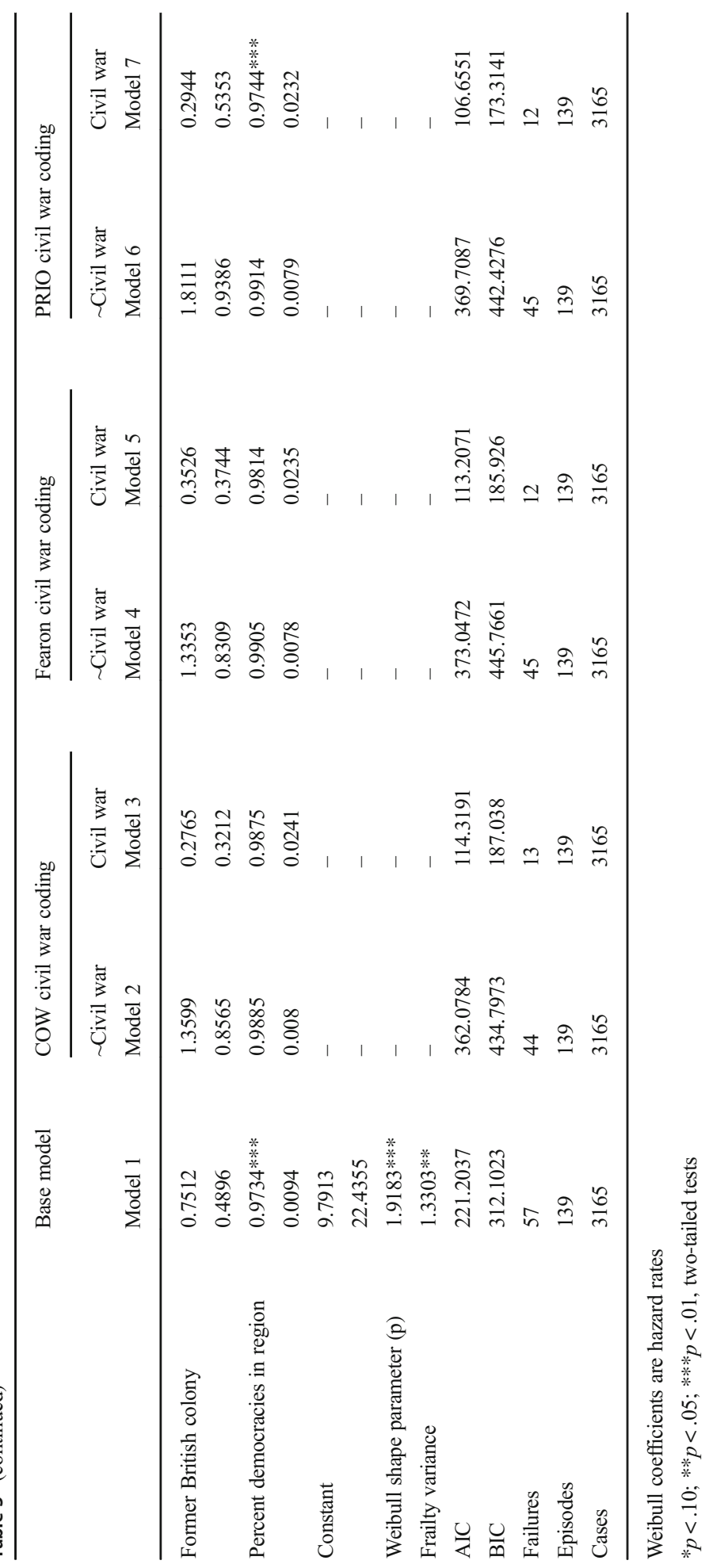


Table 4 Democratic survival by civil society and party institutionalization

\begin{tabular}{|c|c|c|}
\hline & Model 1 & Model 2 \\
\hline \multicolumn{3}{|l|}{ Civil war onset } \\
\hline \multirow[t]{2}{*}{ Civil society } & 0.0907 & 0.1031 \\
\hline & 0.1285 & 0.1315 \\
\hline \multirow[t]{2}{*}{ Party institutionalization } & -0.6123 & -0.7663 \\
\hline & 0.6567 & 0.6833 \\
\hline \multirow[t]{2}{*}{ Repress } & $1.0959 * * *$ & $1.5592 * * *$ \\
\hline & 0.1943 & 0.3862 \\
\hline \multirow[t]{2}{*}{ DissACt } & $0.794 * * *$ & -0.0109 \\
\hline & 0.2644 & 0.6312 \\
\hline \multirow[t]{2}{*}{ DissACt Res } & - & 0.8653 \\
\hline & - & 0.7354 \\
\hline \multirow[t]{2}{*}{ Repress Res } & - & -0.53 \\
\hline & - & 0.5472 \\
\hline \multirow[t]{2}{*}{ Wart-1 } & $-3.0064 * * *$ & $-3.031 * * *$ \\
\hline & 0.5611 & 0.6271 \\
\hline \multirow[t]{2}{*}{ Resources } & $-0.2979 * * *$ & $-0.2488^{* * * *}$ \\
\hline & 0.0735 & 0.0777 \\
\hline \multirow[t]{2}{*}{ Population } & 0.0738 & 0.0262 \\
\hline & 0.1308 & 0.1485 \\
\hline \multirow[t]{2}{*}{ Mountains } & 0.0817 & 0.0738 \\
\hline & 0.1156 & 0.1195 \\
\hline \multirow[t]{2}{*}{ Noncontig } & $1.3236^{* * *}$ & $1.5939 * * *$ \\
\hline & 0.4994 & 0.4976 \\
\hline \multirow[t]{2}{*}{ Oil } & 0.0964 & -0.0863 \\
\hline & 0.3532 & 0.3573 \\
\hline \multirow[t]{2}{*}{ Democracy } & 0.0218 & 0.0405 \\
\hline & 0.0339 & 0.0405 \\
\hline \multirow[t]{2}{*}{ New state } & $2.6645^{* * *}$ & $3.1539 * * *$ \\
\hline & 0.7434 & 0.7346 \\
\hline \multirow[t]{2}{*}{ Instability } & 0.0916 & 0.1624 \\
\hline & 0.3628 & 0.3719 \\
\hline \multirow[t]{2}{*}{ Ethnic Frac } & 0.8623 & 1.0217 \\
\hline & 0.5771 & 0.6246 \\
\hline \multirow[t]{2}{*}{ Relig Frac } & -0.3831 & -0.603 \\
\hline & 0.7943 & 0.8423 \\
\hline \multirow[t]{2}{*}{ Constant } & $-7.8874 * * *$ & $-8.3302 * * *$ \\
\hline & 1.3746 & 1.3327 \\
\hline Number of imputations & 5 & 5 \\
\hline Episodes & 150 & 150 \\
\hline Cases & 3404 & 3404 \\
\hline
\end{tabular}

Weibull coefficients are hazard rates

$* p<.10, * * p<.05, * * * p<.01$, two-tailed tests 
Open Access This article is licensed under a Creative Commons Attribution 4.0 International License, which permits use, sharing, adaptation, distribution and reproduction in any medium or format, as long as you give appropriate credit to the original author(s) and the source, provide a link to the Creative Commons licence, and indicate if changes were made. The images or other third party material in this article are included in the article's Creative Commons licence, unless indicated otherwise in a credit line to the material. If material is not included in the article's Creative Commons licence and your intended use is not permitted by statutory regulation or exceeds the permitted use, you will need to obtain permission directly from the copyright holder. To view a copy of this licence, visit http://creativecommons.org/licenses/by/4.0/.

\section{References}

Acemoglu D, Robinson J. Economic origins of dictatorship and democracy. Cambridge: Cambridge University Press; 2006.

Altman D. Citizenship and contemporary direct democracy. New York: Cambridge University Press; 2019.

Alvarez M, Cheibub JA, Limongi F, Przeworski A. Classifying political regimes. Stud Comp Int Dev. 1996;31:3-36.

Anderson C. The end of economic voting? Annu Rev Polit Sci. 2007;10:271-96.

Arato A. Civil society and the state, Poland 1980-81. In: From neo-Marxism to democratic theory. Armonk: M.E. Sharpe; 1993. p. 171-211.

Ashworth S. Electoral accountability. Annu review. Polit Sci. 2012;15:183-201.

Berman S. Civil society and the collapse of the Weimar republic. World Polit. 1997;59:401-29.

Bermeo N. Ordinary people in extraordinary times: the citizenry and the breakdown of democracy. Princeton: Princeton University Press; 2003.

Bermeo N. On democratic backsliding. J Democr. 2016;27:5-19.

Bernhard M, Karakoç E. Civil society and the legacies of dictatorship. World Polit. 2007;59:539-67.

Bernhard M, Reenock C, Nordstrom T. The legacy of western overseas colonialism on democratic survival. Int Stud Quart. 2004;48:225-50.

Bizzarro F, Hicken A, Self D. The V-Dem party institutionalization index: a new global indicator (1900-2015). Varieties of democracy institute working paper; 2017, No. 48.

Boix C. Democracy and redistribution. Cambridge: Cambridge University Press; 2003.

Boix C, Miller M, Rossato S. A complete data set of political regimes, 1800-2007. Comp Polit Stud. 2013;46: 1523-54.

Bollen KA, Paxton P. Subjective measures of liberal democracy. Comp Polit Stud. 2000;37:58-86.

Brancati D. Democracy protests: origins, features and significance. New York: Cambridge University Press; 2016.

Bratton M, Masunungure E. Popular reactions to state repression: operation Murambatsvina in Zimbabwe. Afr Affairs. 2007;106:21-45.

Brunkert L, Kruse S, Welzel C. A tale of culture-bound regime evolution: the centennial democratic trend and its recent reversal. Democratization. 2018;26:422-43.

Bunce V, Wolchik S. Defeating authoritarian leaders in postcommunist countries. Cambridge: Cambridge University Press; 2011.

Capoccia G. Defending democracy: reactions to extremism in interwar Europe. Baltimore: Johns Hopkins University Press; 2005.

Carreras MJ. The rise of outsiders in Latin America, 1980-2010. Comp Polit Stud. 2012;45:1451-82.

Chalmers DA, Martin SB, Piste K. Associative networks: new structures of representation for the popular sectors? In: Chalmers DA, Vilas CM, Hite K, Martin SB, Piester K, Segarra M, editors. The new politics of inequality in Latin America. Oxford: Oxford University Press; 1997. p. 543-82.

Cheibub JA. Presidentialism, parliamentarism, and democracy. New York: Cambridge University Press; 2007.

Chenoweth E, Lewis O. Unpacking nonviolent campaigns: introducing the NAVCO 2.0 dataset. J Peace Res. 2013;50:415-23.

Coppedge M, Gerring J, Lindberg SI, Skaaning S, Teorell J, Altman D, Andersson F, Bernhard M, Fish MS, Hicken AA, Knutsen CH, McMann K, Mechkova V, Miri F, Paxton P, Pemstein D, Sigman R, Staton J, Zimmerman, B. 2016a. V-Dem codebook v6. Varieties of democracy project.

Coppedge M, Gerring J, Lindberg SI, Skaaning S, Teorell J, Altman D, Andersson F, Bernhard M, Fish MS, Hicken AA, Knutsen CH, Mcmann K, Mechkova V, Miri F, Paxton P, Pemstein D, Sigman R, Staton J, Zimmerman, B. 2016b. V-Dem [country-year/country-date] dataset v6. Varieties of democracy project. 
Cornell A, Grimes M. Institutions as incentives for civic action: bureaucratic structures, civil society, and disruptive protests. J Polit. 2015;77:664-78.

Corrales J. Autocratic legalism in Venezuela. J Democr. 2015;26:37-51.

Crowd Counting Consortium. 2019. Home page [online]. Available at: https://sites.google. com/view/crowdcountingconsortium/home. Accessed 22 July 2019.

Dahl R. Polyarchy. New Haven: Yale University Press; 1971.

Deegan-Krause K. Elected affinities: democracy and party competition in Slovakia and the Czech Republic. Palo Alto: Stanford University Press; 2006.

Deegan-Krause K, Haughton T. Toward a more useful conceptualization of populism. Politics\&Policy. 2009;37:821-41.

Della Porta D. Mobilizing for democracy. Oxford: Oxford University Press; 2014.

Diamond L. Rethinking civil society. J Democr. 1994;5:4-17.

Diamond L. Facing up to the democratic recession. J Democr. 2015;26:141-55.

Ekiert G, Kubik J. Contentious politics in new democracies: East Germany, Hungary, Poland, and Slovakia, 1989-93. World Polit. 1998;50:547-81.

Esen B, Gumuscu S. Rising competitive authoritarianism in Turkey. Third World Q. 2016;37:1581-606.

Fishman R. How civil society matters in democratization. Comp Polit. 2017;49:391-409.

Flores-Macías GA. The macroeconomic consequences of PSI. In: Mainwaring S, editor. Party systems in Latin America. New York: Cambridge University Press; 2018. p. 408-25.

Gasiorowski MJ. Economic crisis and political regime change. Am Polit Sci Rev. 1995;89(4):882-97.

Grimes M. The contingencies of societal accountability: examining the link between civil society and good government. Stud Comp Int Dev. 2013;48(4):380-402.

Haggard S, Kaufman R. Democrats and dictators: masses, elites, and regime change. Princeton: Princeton University Press; 2016.

Haughton T. Facilitator and impeder: the institutional framework of Slovak politics during the premiership of Vladimír Mečiar. Slavon E Eur Rev. 2003;81:267-90.

Hegre H, Bernhard M, Jan TJ. Civil society and the democratic peace. J Conflict Resolut (Published on-line May 30. 2019). https://doi.org/10.1177/0022002719850620 .

Hicken A. Party systems and the politics of development. In: Lancaster C, Van de Walle N, editors. The Oxford handbook of the politics of development. New York: Oxford University Press; 2016. p. 499-516.

Hicken A, Kuhonta EM. Rethinking party system institutionalization in Asia. In: Hicken A, Kuhonta EM, editors. Party and party system institutionalization in Asia. New York: Cambridge University Press; 2014. p. 1-24.

Houtzager PP, Lavalle AG. Civil society's claims to political representation in Brazil. Stud Comp Political Dev. 2010;45:1-29.

Jackman S. What do we learn from graduate students committees? A multiple rater, latent variable model, with incomplete and continuous indicators. Polit Anal. 2004;12:400-24.

Keck M, Sikkink K. Activists beyond borders. Ithaca: Cornell University Press; 1998.

Kenney CD. Outsider and anti-party politicians in power: new conceptual strategies and empirical evidence from Peru. Party Polit. 1998;4:57-75.

King G, Wand J. Comparing incomparable survey responses: evaluating and selecting anchoring vignettes. Polit Anal. 2007;15:46-66.

Kitschelt H, Hawkins KA, Luna JP, Rosa G, Zechmeister EJ. Latin American party systems. New York: Cambridge University Press; 2010.

Kneuer M. Deficits in democratic quality? The effects of party-system institutionalisation on the quality of democracy in Central Eastern Europe. In: Erdmann G, Kneuer M. editors. Regression of democracy? Zeitschrift für Vergleichende Politikwissenschaft 2011; Special Issue 1: 133-172.

Kornai J. Hungary's U-turn: retreating from democracy. J Democr. 2015;26:34 48.

Korolczuk E. Explaining mass protests against the abortion ban in Poland. Zoon Politikon. 2016;7:91-113.

Leff CS. Dysfunctional democratization? Probl Post-Communism. 1996;43:36-51.

Levitsky S. Institutionalization and peronism. Party Polit. 1998;4:77-92.

Levitsky S. Peru: the institutionalization of politics without parties. In: Mainwaring S, editor. Party Systems in Latin America: institutionalization, decay, and collapse. Cambridge: Cambridge University Press; 2018. p. 326-56.

Levitsky S, Way L. Competitive authoritarianism: hybrid regimes after the cold war. Cambridge: Cambridge University Press; 2010.

Lewis PG. Party systems in post-communist Central Europe. Democratization. 2006;13:562-83.

Linz J. The dreakdown of democratic regimes. Baltimore: Johns Hopkins University Press; 1978. 
Linz J. Presidential or parliamentary democracy: does it make a difference? In: Linz J, Valenzuela A, editors. The failure of presidential democracy. Baltimore: The Johns Hopkins University Press; 1994. p. 3-88.

Lipman M. At the turning point to repression: why there are more and more "undesirable elements" in Russia? Russ Polit Law. 2016;54:341-50.

Lipset SM. Some social requisites of democracy. Am Polit Sci Rev. 1959;53:69-105.

Lührmann A, Lindberg SI. A third wave of autocratization is here: what is new about it? Democratization. 2019;26:1095-113.

Lupu N, Riedl RB. Political parties and uncertainty in developing democracies. Comp Polit Stud. 2013;46: 1339-65.

Maddison A. The maddison-project. 2013 version http://www.ggdc.net/maddison/maddison-project/home. htm. Accessed 13 May 2016.

Mainwaring S. Party systems in the third wave. J Democr. 1998;9:67-81.

Mainwaring S. Party system institutionalization, predictability, and democracy. In: Mainwaring S, editor. Party systems in Latin America: institutionalization, decay, and collapse. Cambridge: Cambridge University Press; 2018. p. 71-101.

Mainwaring S, Scully T, editors. Building democratic institutions: party systems in Latin America. Stanford: Stanford University Press; 1995.

Mainwaring S, Torcal M. Party system institutionalization and party system theory after the third wave of democratization. In: Katz RS, Crotty W, editors. Handbook of political parties. London: Sage; 2006. p. 204-27.

Manin B, Przeworski A, Stokes S. Elections and representation. In: Przeworski A, Stokes S, Manin B, editors. Democracy, accountability, and representation. Cambridge: Cambridge University Press; 1999. p. 29-54.

Marquandt K, Pemstein D. IRT models for expert-coded panel data. Varieties of Democracy Institute Working Paper Series 2017; No. 41.

McAdam D, Tarrow S. Ballots and barricades: on the reciprocal relationship between elections and social movements. Perspect Polit. 2010;8:529-42.

Miller M. Democratic pieces: autocratic elections and democratic development since 1815. Brit J Polit Sci. 2015;4:501-30.

Morgan J. Bankrupt representation and party system collapse. University Park: Penn State Press; 2011.

Moser RG, Scheiner E. Electoral systems and political context. New York: Cambridge University Press; 2012.

Nardulli PF, Wong CJ, Singh A, Peyton B, Bajjaliegh J. The composition of religious and ethnic groups (CREG) project. Urbana-Champaign: Cline Center for Democracy, University of Illinois; 2012. http://www.clinecenter.illinois.edu/publications/CREG-White Paper.pdf.

Nohlen D, Stöver P. Elections in Europe. Baden-Baden: Nomos Verlagsgesellschaft; 2010.

North DC, Summerhill W, Weingast B. Order, disorder, and economic change. In: Buena de Mesquita B, Root H, editors. Governing for Prosperity. New Haven: Yale University Press; 2000. p. 17-58.

O’Donnell G. Horizontal accountability in new democracies. J Democr. 1998;9:112-26.

O’Donnell G, Schmitter PC. Tentative conclusions about uncertain democracies. In: O'Donnell G, Schmitter PC, Whitehead L, editors. Transitions from authoritarian rule, vol. 4. Baltimore: Johns Hopkins University Press; 1986. p. 1-72.

O'Dwyer C. Runaway state-building: patronage politics and democratic development. Baltimore: Johns Hopkins University Press; 2006.

Pemstein D, Meserve SA, Melton J. Democratic compromise: a latent variable analysis of ten measures of regime type. Polit Anal. 2010;18:426-49.

Pemstein D, Tzelgov E, Wang Y. Evaluating and improving item response theory models for cross-national expert surveys. Varieties of Democracy Institute Working Paper Series; 2015. No. 1.

Peruzzotti E, Smulovitz C. Social accountability. In: Peruzzotti E, Smulovitz C, editors. Enforcing the rule of law: social accountability in the new Latin American democracies. Pittsburgh: University of Pittsburgh Press; 2006. p. 3-33.

Potocki R. Slovakia's elections: outcomes and consequences. Explore Publications 2011; 167. https://www. wilsoncenter.org/publication/167-slovakias-elections-outcomes-and-consequences. Accessed 10 Apr 2017.

Przeworski A. Democracy and the market. Cambridge: Cambridge University Press; 1991.

Przeworski A, Limongi F. Modernization: theories and facts. World Polit. 1997;49:155-83.

Putnam RD. Making democracy work. Princeton: Princeton University Press; 1993.

Reidl RB. Authoritarian origins of democratic party systems. Cambridge: Cambridge University Press; 2014.

Riley DJ. The civic foundations of fascism in Europe. Baltimore: Johns Hopkins University Press; 2010.

Rueschemeyer D, Stephens J, Stephens EH. Capitalist development and democracy. Chicago: University of Chicago Press; 1992. 
Samuels DJ, Shugart MS. Presidents, parties, and prime ministers. New York: Cambridge University Press; 2010.

Sartori G. Parties and party systems. New York: Cambridge University Press; 1976.

Schmitter P. The consolidation of democracy and representation of social groups. Am Behav Sci. 1992;35: $422-49$.

Self D, Hicken, A. Why populism? How parties shape the electoral fortune of populists. V-Dem Working Paper 2018; No. 76.

Smulovitz C, Peruzzotti E. Societal accountability in Latin America. J Democr. 2000;11:147-58.

Staton J. Judicial power and strategic communication in Mexico. Cambridge: Cambridge University. Press; 2010.

Stepan A. State power and the strength of civil society in the southern cone of Latin America. In: Evans PB, Rueschemeyer D, Skocpol T, editors. Bringing the state back in. Cambridge: Cambridge University Press; 1985. p. 317-46.

Svolik M. Authoritarian reversals and democratic consolidation. Am Polit Sci Review. 2008;102:153-68.

Trier S, Jackman S. Democracy as a latent variable. Am J Polit Sci. 2008;52:201-17.

Ufen A. Political party and party system institutionalization in Southeast Asia. Pac Rev. 2008;21:327-50.

Vanberg G. Legislative-judicial relations: a game-theoretic approach to constitutional review. Am J Polit Sci. 2001;45:346-61.

Vanberg G. The politics of constitutional review in Germany. Cambridge: Cambridge University. Press; 2005.

Waldner D, Lust E. Unwelcome change: coming to terms with democratic backsliding. Annu Rev Polit Sci. 2018;21:93-113.

Publisher's Note Springer Nature remains neutral with regard to jurisdictional claims in published maps and institutional affiliations.

Michael Bernhard holds the Raymond and Miriam Ehrlich Chair in Political Science at the University of Florida. He is the editor-in-chief of Perspectives on Politics. His work centers on questions of democratization and development, both globally and in the context of Europe. Among the issues that have figured prominently in his research agenda are the role of civil society in democratization, institutional choice in new democracies, the political economy of democratic survival, the legacy of extreme forms of dictatorship, and the politics of memory. He is currently working on a co-authored book on the long-term impact of Leninist violence on postcommunist regime formation.

Allen Hicken is Professor of Political Science, a Research Professor at the Center for Political Studies, and Faculty Affiliate of the Center for Southeast Asian Studies at the University of Michigan. He studies political parties, institutions, clientelism, political economy, and policy making in developing countries, with a focus on Southeast Asia.

Christopher Reenock is an Associate Professor in Political Science at Florida State University. His research focusses on questions of democratization and comparative public policy. His work has appeared in several leading journals and has been supported by the National Science Foundation. He is currently working on a coauthored book on judicial independence, democracy, and the politics of prudence.

Staffan I. Lindberg is a founding Principal Investigator (PI) of V-Dem, Director of the V-Dem Institute, Professor of Political Science at the University of Gothenburg, Wallenberg Academy Fellow, and awardee of an ERC Consolidator Grant. He has published almost 50 articles and books on elections and democratization, party and electoral systems, accountability, democratization, popular attitudes, egalitarian democracy, sequence analysis methods, civil society, electoral fraud, corruption, women's empowerment and representation, political clientelism, voting behavior and turnovers, the Ghanaian legislature, and executive-legislative relationships. Lindberg has also extensive experience as consultant on development and democracy, and advising policy-practitioners' organizations. 